\title{
Ekonomi Indonesia dalam perspektif hukum berkeadilan
}

\author{
Riski Febria Nurita ${ }^{1}$, La Rian Hidayat ${ }^{2}$
}

${ }^{1}$ Riski Febria Nurita; Fakultas Hukum Universitas Merdeka Malang; Jl. Terusan Raya Dieng Nomor 6264; Malang; 65146; Jawa Timur; Indonesia.

${ }^{2}$ La Rian Hidayat; Fakultas Hukum Universitas Merdeka Malang; Jl. Terusan Raya Dieng Nomor 62-64; Malang; 65146; Jawa Timur; Indonesia.

\section{ARTICLEINFO}

Article history:

Received 2020-09-12

Received in revised form

2020-10-12

Accepted 2020-12-01

Kata kunci:

Ekonomi; Keadilan Sosial; Pancasila.

Keywords:

Economy; Social Justice; Pancasila.

DOI: https://doi.org/10.26905/

idjch. v11i3. 5474.

How to cite item:

Nurita, R., \& Hidayat, L. (2020).

Ekonomi Indonesia dalam perspektif hukum berkeadilan. Jurnal Cakrawala Hukum, 11(3). 259-270. doi:10.26905/

idjch.v11i3.5474.

Corresponding Author:

* Riski Febria Nurita.

E-mail address: riski.febria@unmer.ac.id 


\section{Jurnal Cakrawala Hukum, Volume 11 No. 3 Desember 2020}

ISSN PRINT 2356-4962 ISSN ONLINE 2598-6538

through me from the founders of the nation in article 33 is close they can traced through the study of judicial political . The most number of pancasila economic is a system a different economy with sitem a capitalist economy. The economic system is the most number of pancasila the economic system of being imbued by the ideology of the most number of pancasila, i e the system degenerative brain malady that is economic joint business that evenly distributed the kinsfolk and mutual cooperation national level to social realize the manifestation of justice for all people of Indonesia.

\section{Pendahuluan}

Menurut Louis Kelso dan Mortimer Adler, dalam konsep keadilan ekonomi, terdapat tiga prinsip esensial yang bersifat interdependen, yaitu partisipasi, distribusi, dan harmoni. Ketiganya menopang bangunan keadilan ekonomi dalam masyarakat. Jika satu di antaranya hilang, niscaya bangunan keadilan menjadi runtuh.

Konsep pembangunan Indonesia itu sendiri merupakan upaya pembangunan yang berkesinambungan dalam rangka mewujudkan masyarakat Indonesia yang adil dan makmur berdasarkan Pancasila dan Undang-Undang Dasar Negara Republik Indonesia tahun 1945 (UUD NRI 1945), sehingga mampu menghadapi perkembangan perekonomian yang senantiasa bergerak cepat, kompetitif, dan terintegrasi dengan tantangan yang semakin kompleks.

Dalam pasal 33 UUD Negara Republik Indonesia Tahun 1945 telah mengatur tentang perekonomian nasional dan kesejahteraan sosial. Pikiran dan ide dari para pendiri Bangsa dalam pasal 33 tersebut dapat ditelusuri melalui studi Hukum Politik. Penelusuran dapat dilakukan dengan menggunakan pendekatan kesejarahan untuk mengeksplorasi ide-ide dari para perumus saat menyusun Pasal 33 tersebut. Pikiran dan ide dari para perumus menjadi objek analisis yang dapat kita telusuri. Pertama, keseriusan negara dalam melindungi seluruh bangsa dan tumpah darah air Indonesia yang berdasarkan konsep negara kesatuan dalam upaya nyata untuk mewujudkan keadilan sosial. Kedua konsep "Kesejahteraan
Sosial", dimaksudkan untuk menjamin kesejahteraan kepada negara dan seluruh rakyat Indonesia. Ketiga, para perumus berkomitmen dan yakin bahwa cita-cita keadilan sosial dalam perekonomian dapat mencapai kemakmuran yang adil dan beradab. Keempat, bahwa para perumus mensyaratkan negara hanya boleh melakukan pemeliharaan dan proses, dan bukan berpemilik.

Dalam mengantisipasi era persaingan global saat ini, kepastian hukum sangat dibutuhkan, hal ini dilakukan untuk memperoleh jaminan dalam setiap pelaksanaan ekonomi yang dilakukan ole warga negara. Namun demikian, akan terlalu kaku apabila kita hanya berpegang pada kepastian hukum itu sendiri, karena akan muncul kesulitankesulitan, mengingat ekonomi akan terus berkembang seiring dengan kemajuan zaman. Secara umum dapat diketahui bahwa perkembangan antara hukum dan ekonomi tidak berjalan seimbang. Disatu sisi, hukum akan tertinggal jauh dengan laju perkembangan ekonomi. Oleh karenanya, tidak jarang dalam suatu negara (termasuk Indonesia) pranata hukumnya yang mengatur ekonomi terkesan berubah-ubah.

Dalam penjelasan Pasal 33 UUD NRI 1945 menyebutkan dasar demokrasi ekonomi adalah produksi dikerjakan oleh semua untuk semua. Kemakmuran masyarakat yang diutamakan bukan kemakmuran orang perorang. Cabang-cabang produksi yang penting bagi negara dan yang menguasai hajat hidup orang banyak harus dikuasai oleh negara dan dipergunakan sebesarbesarnya untuk kesejahteraan masyarakat. Apabila tidak, maka tampuk produksi akan jatuh ke tangan 


\section{Ekonomi Indonesia dalam perspektif hukum berkeadilan}

Riski Febria Nurita, La Rian Hidayat

orang perorangan yang berkuasa dan memiliki modal besar, dan akibatnya rakyat menjadi korban penindasan ekonomi.

Membaca amanah konstitusi tentang perekonomian nasional, maka sebetulnya tidak ada alasan bagi pemerintah untuk tidak berpihak kepada masyarakat banyak. Karena oleh konstitusi para pemegang kebijakan di instruksikan untuk tidak bersikap netral dalam mengatasi persoalan ekonomi, dan membiarkan persoalan ekonomi menjadi objek pasar tanpa harus negara ikut campur dalam menanganinya. Dengan negara berpihak kepada rakyat banyak itu sama artinya negara menolong kaum-kaum lemah (mustadh'afin). Oleh karena itu, jika dalam praktek terjadi benturan kepentingan antara rakyat dengan orang perorang (korporasi), maka negara harus dengan tegas membela epentingan rakyat. Artinya kepentingan ekonomi rakyat yang harus diutamakan.

Jika pemerintah sudah bertekad memegang garis tegas amanah konstitusi maka segala persoalan deregulasi dan paket peraturan yang dikeluarkan dan terkesan berubah-ubah dan tidak sesuai dengan amanat konstitusi maka tidak akan pernah terjadi. Karena pemerintah tau itu tidak sesuai dan bertentangan dengan keinginan para para perumus konstitusi indonesia dahulu. Dengan demikian upaya pemerintah adalah berusaha semaksimal mungkin membuat Undang-Undang yang hanya memuat prinsip-prinsip umum ekonomi rakyat sebagai penafsiran lebih lanjut dari konstitusi. Sedangkan hal-hal yang sifatnya teknis operasional diserahkan pada peraturan yang ada dibawahnya atau bila perlu diserahkan pada yang lebih rendah sehingga memudahkan pemerintah mengubah bila sewaktu-waktu memang diperlukan untuk melakukan perubahan.

\section{Metode}

Jenis penelitian yang digunakan, Jenis penelitian ini adalah penelitian Normatif, dengan per- timbangan karena sasaran dari penelitian ini adalah mengkaji sistem ekonomi di Indonesia berdasarkan sudut pandang hukum. Oleh karena itu pendekatan yang digunakan adalah Statute Approach dengan mengkaji sebuah peraturan perundangundangan yang berhubungan dengan tema sentral penelitian.

\section{Pembahasan}

\subsection{Pasal 33 UUD Negara Republik Indonesia Tahun 1945 sebagai representasi asli ekonomi Indonesia}

Pada masa perkembangan konstitusi medern seperti sekarang ini, prinsip konstitusionalisme telah memberikan kerangka konsep negara konstitusional dengan karakteristik konstitusi sebagai norma hukum tertinggi. Selaras dengan pendapat Francois Venter bahwa karakteristik dasar sebuah negara konstitusional modern adalah adanya sebuah konstitusi tertulis yang memiliki nilai hukum yang tinggi (Indrayana, 2007). Dalam prakteknya, konstitusi sebagai norma hukum tertinggi menjadi sarana penting untuk melindungikepentingan masyarakat ditengah koruptifnya dan potensi otoritarianisme yang dihadapkan oleh seorang pemimpin di suatu negara.

Konstitusi memang di idealkan menjadi jembatan antara rakyat dan nagara. Salah satunya seperti yang terdapat dalam Pasal 33 UUD NRI 1945.

Pasal 33 UUD NRI 1945 hasil amandemen yang terdiri dari 5 ayat tersebut merupakan norma dasar yang menjadikan kebijakan ekonomi yang menjadi landasan arah kebijakan ekonomi nasional. Pasal 33 UUD NRI 1945 yang selanjutnya dijabarkan kedalam undang-undang dan peraturan perundang-undangan lainnya sebagai kebijakan hukum dalam hal perekonomian yang lebih operasional. Pasal 33 UUD NRI 1945 merupakan norma hukum konstitusional yang bersifat mutlak dan tidak boleh dilanggar oleh penentu kebijakan 


\section{Jurnal Cakrawala Hukum, Volume 11 No. 3 Desember 2020}

ISSN PRINT 2356-4962 ISSN ONLINE 2598-6538

ekonomi. Kebijakan ekonomi harus mengacu dan tidak boleh bertentangan dengan konstitusi sehingga para penentu kebijakan ekonomi tidak boleh membuat kebijakan ekonomi yang bertentangan dengan Pasal 33 UUD NRI 1945 (Asshidiqie, 2010).

Dengan mendudukan hukum sebagai hukum tertinggi, harus menundukkan Pasal 33 UUD NRI 1945 yang mengatur tentang perekonomian nasional sebagai norma tertinggi yang spiritnya harus membumikan prinsip-prinsip dasar perekonomian. Spirit konstitusi khususnya yang menyangkut Pasal 33 UUD NRI 1945 tersebut akan dielaborasi dengan pendekatan politik hukum dalam konteks sejarah saat pembentukan Pasal 33 UUD NRI 1945. Politik hukum merupakan arah kebijakan hukum yang diterapkan saat penyusunan suatu produk hukum. Menurut Mahfud MD, politik hukum dipahami sebagai kebijaksanaan hukum yang akan atau telah dilaksanakan secara nasional oleh pemerintah (Arinanto, 2015). Dalam hal ini politik hukum merupakan kebijaksanaan hukum diterapkan terhadap pilihan hukum dalam rangka suatu pencapaian tujuan tertentu. Artinya, kebijaksanaan hukum ditentukan dalam penyusunan hukum sebagai bentuk rekayasa hukum mencapai tujuan hukum tertentu sebagaimana yang dicita-citakan dalam konstitusi. Dalam hal ini kebijaksanaan hukum harus diarahkan untuk menggali cita-cita para pendiri bangsa dalam membentuk Pasal 33 UUD NRI 1945 (Syahuri, 2012).

Pancasila sila kelima "Keadilan sosial bagi seluruh rakyat Indonesia" merupakan jiwa filosofis dari Pasal 33 UUD NRI 1945. Ada prinsip yang kuat yang diemban oleh sila kelima Pancasila terkait dengan konsep keadilan dalam mewujudkan kesejahteraan bagi seluruh rakyat Indonesia. Menurut Yudi Latif, otensitas sila kelima ditunjukan dengan kesungguhan negara dalam melindungi segenap bangsa dan seluruh tumpah darah Indonesia berdasarka persatuan sebagai usaha nyata mewujudkan keadilan sosial. Pada saat menyampaikan pidato dalam rapat BPUPK pada tanggal 1 Juni 1945, Soekarno menggagas adanya suatu konsep "Kesejhteraan Sosial" yang dimaksudkan agar negara memberikan jaminan kesejahteraan dan pemerintahan kepada seluruh rakyat (Syahuri, 2012).

Namun jika dilihat dalam pelaksanaannya, realita dari pasal 33 UUD NRI 1945 mengalami dinamika. Pada masa pemerintahan Presiden Soekarno, sebagai damapak dari revolusi fisik dan belum pulihnya infrastruktur pascaperang, orientasi produksi diarahkan untuk ekspor mengingat sektor industri seperti pertambangan, perbankan, dan pertanian komersial masih dikuasai oleh perusahaan asing. Pada era orde baru, Presiden Soeharto mengambil kebijakan terkait kekuasaan negara atas sumber daya alam diwujudkan dalam bentuk pendirian badan usaha milik negara (Latif: 2011).

\subsection{Kritik kapitalisme ekonomi oleh teori marxis dan neo Marxian terhadap sistem keadilan sosial}

Tujuan Marx adalah untuk memperjelas aspek sosial dan politis dari ekonomi dengan memperlihatkan "hukum gerak ekonomi masyarakat modern". Selain itu, Marx juga inhgin memperlihatkan kontradiksi-kontradiksi internal yang dia pikirkan akan mengubah kapitalisme. Pada masa Marx,Eropa mengalami peningkatan industrialisasi yang begitu pesat. Orang-orang dipaksa meninggalkan keterampilan bertani dan pekerjaan tangan dan bekerja di pabrik-pabrik yang syaratsyaratnya seringkali tidak manusiawi. Berbagai pengaruh industrialisasi dan konotasi-konotasi politisnya sangat jelas terlihat pada kelompok yang kebanyakan mendiami wilayah-wilayah pedalaman yang secara kolektif merujuk kepada Jerman. Pada awal abad ke-20, barang-barang pabrik yang murah dari Inggris dan Prancis mulai menghancurkan pabrik-pabrik milik pengusaha yang kurang efisien di Jerman. Sebagai responnya, 


\section{Ekonomi Indonesia dalam perspektif hukum berkeadilan}

Riski Febria Nurita, La Rian Hidayat

negara-negara Jerman menerapkan Kapitalisme kepada masyarakat yang sebagian besar masih feudal. Kemiskinan, penggusuran, dan alienasi yang marak terjadi karena cepatnya perubahan yang terjadi. Hal ini merupakan proses politis sebagaimana juga merupakan proses ekonomis.

Kapitalisme adalah sistem ekonomi di mana sejumlah besar pekerja, yang hanya memiliki sedikit hak milik. memproduksi komoditas-komoditas demi keuntungan sejumlah kecil kapitalis yang memiliki hal-hal berikut: (Goodman, 2011) Komoditas-komoditas, alat-alat produksi, dan bahkan waktu kerja para pekerja karena mereka membeli pekerja tersebut melalui gaji. Namun salah satu pengertian sentral Marx adalah bahwa Kapitalisme lebih bdari sekedar sistem ekonomi. Paling penting lagi, kapitalisme adalah sistem kekuasaa. Rahasia kapitalisme adalah bahwa kekuatan-kekuatan politis telah diubah menjadi relasi-relasi ekonomi. Para kapitalis bisa memaksa para pekerja dengan kewenangan mereka untuk memecat dan menutup pabrik-pabrik. Karena hal inilah, para kapitalis bebas untuk menggunakan paksaan yang kasar. Maka kapitalisme tidak hanya menjadi sekedar sistem ekonomi, pada saat yang sama, kapitalisme juga merupakan sistem politis, suatu cara menjalankan kekuasaan,dan suatu proses eksploitasi atas para pekerja.

Di bawah kapitalisme, ekonomi tampil kepada kita sebagai kekuatan alamiah. Orang-orang diberhentikan, upah dikurangi, pabrik-pabrik di tutu, itu semua karena "ekonomi". Alasan yang sering diberikan adalah bahwa ekonomi "makin panas", yang artinya ada kemungkinan terjadi inflasi, Peningkatan suku bunga mendinginkan ekonomi, artinya menempatkan orang di luar kerja agar para pekerja takut untuk meminta upah lebih tinggi yang mungkin berdampak pada harga-harga lebih tinggi (Goodman, 2011). Hasilnya,inflasi dapat dicegah, meskipun hal ini dihadirkan sebagai keputusan ekonomi, namun perhatikanlah dimensidimensi politisnya.
Tujuan Marx adalah untuk memperjelas aspek sosial dan politis dari ekonomi dengan memperlihatkan "hukum gerak ekonomi masyarakat modern" (Goodman, 2011). Selain itu Marx juga ingin memerlihatkan kontradiksi-kontradiksi internal yang dia perkirakan akan mengubah kapitalisme. Dua tipe utama yang menjadi perhatian Marx adalah proletariat dan kapitalis, Proletariat adalah para pekerja yang menjual kerja mereka dan tidak memiliki alat-alat produksi sendiri. Mereka tidak memiliki sarana-sarana sendiri dan pabrikpabrik sendiri, tetapi Marx kemudian percaya bahwa proletariatbahkan akan kehilangan keterampilan mereka seiring dengan meningkatnya mesin-mesin yang menggantikan keterampilan mereka.Hal inilah yang membuat proletariat tergantung pada orang yang memberi upah.

Orang yang memberi upah itu adalah Kapitalis. Jelas kapitalis adalah orang-orang yang memiliki alat-alat produksi. Bagaimanapun, sebelum kita mengerti sepenuhnya apa itu kapitalis, kita harus mengerti dahulu apa itu capital. Kapital adalah uang yang menghasilkan lebih banyak uang (Goodman, 2011). Dengan kata lain, capital lebih merupakan uang yang diinvestasikan ketimbang uang yang digunakan untuk memenuhi kebutuhan dan keinginan manusia.

Para pekerja menjadi "buruh-buruh yang bebas", membuat kontrak-kontrak bebas dengan para kapitalis. Namun, Marx percaya bahwa para pekerja harus menaati syarat dan ketentuan kapitalis karena para pekerja tidak lagi mampu memproduksi demi kebutuhan mereka sendiri. Hal ini benar khususnya karena biasanya kapitalisme menciptakan apa yang dirujuk Marx sebagai "tentara cadangan" dari pengangguran. Jika para pekerja tidak mau melakukan tugas dengan upah yang diberikan oleh kapitalis, maka akan ada orang lain di dalam "tentara cadangan" dari pengangguran yang mau melakukannya. Inilah yang misalnya ditemukan Barbara Ehrenreich sebagai tujuan iklan lowongan kerja yang ber-upah rendah. 
Kapitalis membayar para pekerja kurang dari nilai yang mereka hasilkan dan meraup keuntungan untuk diri mereka sendiri.Keinginan untuk memperoleh lebih banyak keuntungan dan lebih banyak nilai tambah untuk ekspansi, mendorong kapitalisme. Ada dua macam kelas yang ditemukan oleh Marx ketika menganalisis kapitalisme yaitu: (Goodman, 2011) borjuis dan proletar. Kelas borjuis merupakan nama khusus untuk para kapitalis dalam ekonomi modern. Mereka memiliki alat-alat produksi dan mempekerjakan pekerja upahan. Konflik antar kelas borjuis dan kelas proletar adalah contoh lain dari kontradiksi material yang sebenarnya. Kontradiksi ini berkembang menjadi kontradiksi anatara kerja dan kapitalisme. Masyarakat akan semakin berisi pertentangan dua kelas besar yang berlawanan. Kompetisi dengan rantai monopoli akan mematikan bisnis-bisnis kecil dan independen, mekanisasi akan menggantikan buruh tangan yang cekatan,Marx menyebut pembengkakan yang terjadi dan tak terelakkan di dalam jumlah proletariat ini dengan proletarianisasi.

Walaupun perhatian utama Marx adalah krisis-krisis yang tak terelakan dari kapitalisme dan gambarannya tentang kapitalisme sebagai suatu sistem dominasi dan eksploitasi, akan tetapi Marx juga melihat kapitalisme sebagai sebagai sesuatu yang baik. Tentu saja Marx tidak ingin kembali pada nilai-nilai tradisional prakapitalisme. Generasi-generasi sebelumnya hanya di eksploitasi, satu-satunya perbedaan hanya bahwa eksploitasi yang dulu tidak diselubungi oleh sistem ekonomi. Terlepas dari sifatnya yang mengeksploitasi, kelahiran kapitalisme membuka kemungkinankemungkinan baru bagi kebebasan para pekerja. Sistem kapitalis membebaskan mereka dari tradisitradisi yang mengungkung masyarakat-masyarakat sebelumnya. Walaupun pekerja belum benarbenar bebas namun ada janji untuk hal itu. Sebagai sistem ekonomi yang paling kuat dan terus berkembang, kapitalisme menjanjikan kebebasan dari kelaparan dan bentuk-bentuk lain dari kekurangan-kekurangan pokok. Dari sudut pandang janji inilah Marx mengkritisi kapitalisme.

\subsection{Ekonomi dan keadilan sebagai tantangan kesejahteraan sosial, perspektif kajian John Rawls dan Francis Fukuyama}

Keadilan merupakan kebijakan utama dalam institusi sosial, sebagaimana kebenaran dalam sistem pemikiran. Suatu teori, betapapun elegan dan ekonomisnya, harus ditolak atau direvisi jika ia tidak benar. Dengan demikian hukum dan institusi, tidak peduli betapapun betapapun efisien dan rapinya, harus direformasi atau dihapuskan jika tidak adil. Keadilan tidak tunduk pada tawar menawar politik atau kalkulasi kepentingan sosial. Satu-satunya hal yang mengijinkan kita untuk menerima sitem yang salah adalah kerena tidak adanya sistem yang lebih baik (Rawls:2011). Secara analogis ketidakadilan bisa kita biarkan hanya ketika ia butuh menghindari ketidakadilan yang lebih besar.

Dalam prinsip ekonomi kesejahteraan, ia seringkali didefinisikan dengan cara yang sama. Kesejahteraan mengisyaratkan bahwa konsepsi moral didalamnya adalah utilitarian. Sebuah doktrin ekonomi politik harus memasukan tafsiran terhadap kebaikan publik yang berdasar pada konsepsi keadilan. Ia juga memandu refleksirefleksi warga ketika mereka mempertimbangkan pertanyaan-pertanyaan tentang kebijakan ekonomi dan sosial. Ia akan mengambil perspektif konvensi konstitusional atau tahap legislatif dan memastikan bagaimana penerapan prinsip-prinsip dari keadilan. Keadilan sebagai fairnesss diterapkan kepada struktur dasar masyarakat.

Sistem ekonomi harus memusatkan perhatiannya pada sektor publik dan bentuk yang tepat dari latarbelakang institusi-institusi yang mengatur aktifitas ekonomi, dengan perpajakan dan hak-hak tanah, struktur pasar dan sebagainya. Sebuah sistem ekonomi mengatur benda-benda apa yang di produksi dan dengan cara apa, siapa yang menerimanaya dan sebagai hasilnya untuk sumbangan apa, dan seberapa besar sebagian sumber daya sosial yang disediakan untuk menye- 


\section{Ekonomi Indonesia dalam perspektif hukum berkeadilan}

Riski Febria Nurita, La Rian Hidayat

lamatkan dan memperlengkapi kebaikan-kebaikan masyarakat.

Oleh karenanya menurut Jhon Rawls penciptaan keadilan dalam aspek sosial baik itu aspek politik, hukum dan atau ekonomi haruslah berdasar pada hak, dan bukan pada manfaat. Dan jika manfaat yang dijadikan dasar dalam penciptaan keadilan maka ia akan mengabaikan prosedur yang fair. Penciptaan keadilan yang berdasarkan pada asas hak akan melahirkan prosedur yang fair karena berdasar pada pada hak-hak individu yang tak boleh dilanggar sama sekali. Penataan sistem sosial yang baik dan benar dirancang tidak hanya untuk memajukan nilai yang baik bagi warganya, melainkan penataan sistem sosial juga harus di tata secara efektif agar dapat menjadi adil. Karena suatu sistem sosial baru dianggap adil apabila memenuhi dua syarat, yaitu: 1 . Setiap orang atau masyarakat mampu menerima dan tahu bahwa yang lainnya juga menerima prinsip keadilan yang sama, 2 . Institusi-institusi sosial pada dasarnya puas dan diketahui oleh prinsip-prinsip dari keadilan tersebut.

Penciptaan lembaga kontrak dan hukum perdagangan merupakan prasyarat penting bagi munculnya ekonomi industri modern saat ini. Hal ini ditujukan agar kemudian terjadi kepastian dalam pelaksanaan dan aktifitas ekonomi masyarakat. dalam konteks ekonomi modern saat ini tidak akan ada seorangpun yang akan membantah bahwa kepercayaan dan kewajiban moral sendiri bisa mengambil tempat bagi perekonomian modern. Dalam bisnis modern seperti sekarang ini, sandaran pada kebiasaan-kebiasaan sosial dan kultural yang selalu sering diterima begitu saja. Lembaga-lembaga modern memang penting, tetapi bukan merupakan syarat yang cukup untuk menciptakan kesejahteraan modern dan kesentosaan sosial. Mereka harus dipadukan dengan kebiasaankebiasaan soaial yang etis tradisional tertentu jika ingin bekerja secara cepat. Amerika Serikat serikat sebagai kekuatan industrial terkemuka di dunia, itu disebabkan karena Amerika memiliki anugerah berupa social capital sosiabilitas spontan. Masyarakat-masyarakat liberal seperti Amerika Serikat memiliki kencendrungan terhadap individualisme dan atomisasi sosial yang secara potensial melemahkan negara. Saat ini Amerika Serikat terjadi kemerosotan kepercayaan dan kebiasaan-kebiasaan sosial yang mendasari kebesarannya sebagai kekuatan industrial modern itu selama kurang lebih setengah abad yang lalu (Fukuyama, 2002).

Kenyataannya akan sangat sulit untuk memahami kehidupan ekonomi dalam ketiadaan level kepercayaan informal minimum. Dalam ungkapan seorang ekonom dan penyair Nobel, Nenneth Arrow, kini kepercayaan memiliki nilai pragmatis yang sangat penting. Kepercayaan adalah pelumas yang penting bagi mulusnya kerja sebuah sistem sosial. Kepercayaan menciptakan efisiensi. Kepercayaan menghemat banyak kesulitan untuk memiliki tingkat keandalan yang adil pada katakata orang lain. Sayangnya kepercayaan bukan komoditas yang bisa dibelidengan sangat mudah. Jika harus anda harus membelinya, berarti anda masih memiliki keraguan tertentu tentang apa yang anda beli.

Pengakuisisian negara dalam berbagai industri dalam sektor-sektor strategi utama tertentu merupakan hal yang baik. Hal ini ditujukan agar tidak terjadi monopoli ekonomi oleh segelintir orang tertentu, disamping itu juga pengakuisisian dipercaya dianggap negara lebih mengenal pasar dimana keuntungan-keuntungan terbaik jangka panjang akan diperoleh.

Konvergensi yang terjadi diseluruh dunia dalam lembaga-lembaga mendasar disekitar demokrasi liberal dan ekonomi-ekonomi pasar memaka kita untuk mengajukan pertanyaan apakah kita telah mencapai "akhir sejarah", dimana proses yang luas dari evolusi historis manusia mencapai titik puncaknya bukan, seperti Marxis, dalam sosialisme, tetapi lebih pada visi Hegel tentang sebuah masyarakat demokrasi liberal borjuis. Memang tidak perlu diragukan bahwa ekonomi-ekonomi modern muncul dari berbagai interak indi- 
vidu rasional yang memaksimalkan kegunaan di pasar-pasar. Namun, maksimalisasi kegunaan tidaklah cukup untuk menjelaskan secara lengkap dan memuaskan tentang mengapa ekonomi negara tertentu berhasil mengalami kemakmuran, sedang yang lain mengalami stagnasi dan kemorosotan (Fukuyama, 2002).

Demokrasi liberal bisa berjalan dengan baik sebagai sistem politik ketika individualismenya dimoderasi oleh semangat publik, demikian juga kapitalisme menjadi lancar ketika individualismenya diimbangi dengan kesiapan untuk berasosiasi. Jika demokrasi dan kapitalisme bekerja dengan baik ketika keduanya dipadukan dengan berbagai tradisi kultural yang muncul dari sumbersumber nonliberal, maka seharusnya jelas bahwa modernitas dan tradisi bisa mengada bersama dalam keseimbangan yang stabil untuk periode waktu yang sangat lama. Proses rasionalisasi ekonomi dan pembangunan merupakan kekuatan sosial yang sangat kuat yang memaksa masyarakat-masyarakat untuk memodernisasi sesuai dengan garisgaris tertentu yang seragam. Misalnya, masyarakat-masyarakat tertentu bisa menghemat biayabiaya transaksi secara substansial karena agenagen ekonomi percaya satu sama lain dala berbagai interaksi sosial ekonomi mereka. Dan oleh karenanya bisa lebih efisien ketimbang masyarakatmasyarakat low-trust, yang memerlukan berbagai kontrak yang rincidan mekanisme-mekanisme pemaksaan. Kepercayaan ini bukanlah konsekuensi dari perhitungan rasional, ia muncul dari sumbersumber seperti agama atau kebiasaan etis yang tidak berkaitan dengan modernitas (Fukuyama: 2002).

\subsection{Ekonomi berwatak pancasila yang ber- keadilan sebuah sumbangsih pemikiran Professor Mubyarto}

Ekonomi Pancasila adalah sistem ekonomi, atau sistem perekonomian tetapi berbeda dengan sitem ekonomi Kapitalis atau sitem ekonomi
Komunis. Sistem ekonomi Pancasila adalah ekonomi yang dijiwai oleh ideologi Pancasila,yaitu sistem ekonomi yang merupakan usaha bersama yang berasaskan kekeluargaan dan kegotong royongan nasional (Mubyarto, 1993). Kegotong royongan nasional,bukan hanya kegotongroyongan di pedesaan, di rukun kampung, tetapi kegotongroyongan pada tingkat nasional. Prof. Mubyarto pun memberikan pemikirannya terhadap apa itu moral ekonomi Pancasila? dapat didefinisikan sebagai kesatuan ukuran, atau norma-norma yang mengatur pola berpikir dan pola bertindak dari pelaku-pelaku ekonomi dalam sistem ekonomi Pancasila.

Pembahasan tentang Ekonomi Pancasila mulai menghangat pada pertengahan Mei 1981. Salah satu sorotan ditujukan pada lima ciri sistem Ekonomi Pancasila,yaitu (Mubyarto, 1993) :1.Roda perekonomian digerakkan oleh rangsangan ekonomi,sosial dan moral; 2. Kehendak kuat dari seluruh masyarakat kearah keadaan kemerataan sosial (egalitarianisme),sesuai asas-asas kemanusiaan; 3. Prioritas kebijakan ekonomi adalah penciptaan perekonomian nasional yang tangguh yang berarti nasionalisme menjiwai tiap kebijaksanaan ekonomi; 4. Koperasi merupakan soko guru perekonomian dan merupakan bentuk yang paling konkrit dari usaha bersama; 5. Adanya imbangan yang jelas dan tegas antara perencanaan di tingkat nasional dengan desentralisasi dalam pelaksanaan kegiatan ekonomi untuk menjamin keadilan ekonomi dan sosial.

Apabila kita renungkan secara benar sila-sila Pancasila sebagaimana tercantum dalam Mukadimah UUD Negara RI 1945, maka akan kita rasakan bahwa pembentukan negara RI yang merdeka dari penjajahan bangsa-bangsa asing, di samping untuk melindungi segenap bangsa, memajukan kesejahteraannnya yang amat penting adalah mewujudkan keadilan sosial bagi seluruh rakyatnya.

Sistem ekonomi sebagai satu subsistem dari sistem sosial politik budaya nasional, harus mampu 


\section{Ekonomi Indonesia dalam perspektif hukum berkeadilan}

Riski Febria Nurita, La Rian Hidayat

mewadahi program-program kegiatan dan kebijaksanaan ekonomi yang mengarah kepada perwujudan keadilan sosial tersebut. Adapun keadilan sosial kiranya dapat didefinisikan sebagai berikut (Mubyarto, 1993).

Keadilan sosial suatu keadaan suasana kehidupan masyarakat di mana setiap warganya merasa aman dan tenteram, lahir dan bati, karena prinsip-prinsip keadilan yang dianggap berlaku dan disetujui masyarakat yang bersangkutan, diakui dan dilaksanakan secara tertib oleh seluruh anggota masyarakat.

Pada dasarnya ada tiga pedoman dasar, bagaimana masyarakat mengatur pembagian rezeki sesuai prinsip keadilan. Pertama, prinsip adanya hak dan kewajiban yaitu bahwa keadilan akan terjaga apabila setiap hak yang terlekat pada seseorang atau lembaga dilindungi, baik oleh peraturan yang dibuat oleh masyarakat sendiri maupun oleh pemerintah. Kedua, Kebiasaan atau tradisi balas membalas yaitu dalam masyarakat yang masih sederhana, orang akan merasa dirinya berbuat tidak adail apabila tidak membalas kebajikan yang telah diterimanya dari orang lain.Pada tingkat pemerintah setiap orang yang berjasa akan diberi penghargaan sesuai dengan jasa-jasanya inilah keadilan. Ketiga, adalah dalam melaksanakan keadilan adalah upaya negara atau organisasi masyarakat untuk memberikan kepada setiap anggotanya apa yang mereka butuhkan. Menurut paham ini, suatu masyarakat dan bahkan negara dapat diibaratkan sebagai suatu keluarga besar, dimana suatu kebutuhan setiap orang tidak sama. Dalam melaksanakan prinsip keadilan, negara diberi hak untuk mengatur siapa mendapat apa, sehingga setiap anggota masyarakat terpenuhi kebutuhannya baik dalam berkonsumsi maupun berproduksi. Demikianlah kaitan antara keadilan sosial dan keadilan ekonomi amat erat hubungannya dengan sistemsistem ekonomi yang dianut suatu masyarakat.

Moralitas ekonomi Pancasila mencakup ajaran-ajaran Ketuhanan, Kemanusiaan, Persatuan,
Kerakyatan, dan Keadilan Sosial. Ciri lain ekonomi Pancasila adalah semangat solidaritas sosial untuk mencapai masyarakat yang berkeadilan sosial, yang merupakan sila kelima dari Pancasila. Masyarakat Pancasila yang berkeadilan sosial adalah masyarakat yang bersifat sosialistik, di mana nasib mereka yang "tertinggal" mendapat perhatian besar. Inilah yang disebutkan pada pasal 34 UUD Negara RI Tahun 1945, bahwa: "Fakir miskin dan anak-anak terlantar dipelihara oleh Negara". Bahkan apa yang tercantum dalam Pasal 33, yang selalu dianggap sebagai pedoman dasar pengelolaan perekonomian Indonesia itu, termasuk dalam bab kesejahteraan sosial. Masyarakat Indonesia yang merdeka, bersatu, berdaulat, adil dan makmur, adalah tujuan perjuangan kemerdekaan Indonesia, tujuan untuk mewujudkan suatu keadilan sosial bagi seluruh rakyat Indonesia.

Keadilan sosial (social justice) merupakan masalah yang sudah lama menjadi perhatian para pemikir, khususnya filosof. Bangsa Indonesia mencantumkan keadilan sosial bagi seluruh rakyat sebagai tujuan akhir yang digambarkan sebagai masyarakat yang adil dan makmur, yang gemah ripah karta raharja,masyarakat yang adil dan makmur karena merupakan wujud akhir dari masyarakat bangsa yang dituju, jelas dimaksudkan sebagai masyarakat yang mengandung sifat-sifat keadilan dan kemakmuran yang lengkap, yang mencakup keadilan hukum, ekonomi, politik, sosial budaya, dan moral.

Secara singkat masyarakat adil dan makmur yang dituju adalah masyarakat adil makmur berdasarkan Pancasila, yaitu masyarakat idaman yang secara lengkap dan utuh didasarkan pada: Ketuhanan Yang Maha Esa, Kemanusiaan yang adil dan beradab, Persatuan Indonesia,dan Kerakyatan yang dipimpin oleh hikmat kebijaksanaan dalam permusyawaratan perwakilan, serta dengan mewujudkan keadilan sosial bagi seluruh rakyat Indonesia. Keadilan sosial bagi seluruh rakyat Indonesia diwujudkan melalui realisasi prinsip 
keadilan dalam tiap-tiap aspek keadilan yaitu seperti yang telah disebutkan sebelumnya yaitu hukum, ekonomi, politik, sosial budaya dan moral yang semuanya berkaitan erat. Namun demikian, ilmu ekonomi dalam sejarahnya lebih banyak sumbangannya pada analisa yang mengakibatkan aspek-aspek ekonomi politik (political economy).

\subsection{Penciptaan public policy oleh government dalam mencapai hukum yang berkeadil- an dalam ranah ekonomi di Indonesia ataukah sebagai penguat kuasa kapitalis}

Kebijakan publik dalam kepustakaan internasional disebut public policy. Harold Laswell dan Abraham Kaplan mendefinisikan public policy sebagai suatu program yang diproyeksikan dengan tujuan-tujuan tertentu, nilai-nilai tertentu, dan praktik-praktik tertentu. Sedangkan Carl I. Friedrick mendefinisikannya sebagai serangkaian tindakan yang diusulkan oleh seseorang, kelompok, atau pemerintah dalam suatu lingkungan tertentu, dengan ancaman dan peluang yang ada. Kebijakan yang diusulkan tersebut ditujukan untuk memanfaatkan potensi sekaligus untuk mengatasi hambatan yang ada dalam rangka mencapai tujuan tertentu. Sebagai sebuah strategi, kebijakan publik tidak saja bersifat positif, namun juga dapat bersifat negatif, dalam artian pilihan keputusan selalu menerima salah satu dan menolak yang lain. Meskipun terdapat ruang bagi win-win dan sebuah tuntutan dapat diakomodasi, pada akhirnya ruang bagi win-win sangat terbatas sehingga kebijakan publik lebih banyak pada ranah zero sum game, yaitu menerima yang ini dan menolak yang lain (Nugroho, 2009).

Kebijakan publik tidak dibuat dalam keadaan vakum. Kebijakan publik banyak dipengaruhi oleh oleh kondisi sosial dan ekonomi, nilai politik yang berlaku dan suasana hati masyarakat pada suatu waktu. Maka, harus ada konteks yang memicu kelahiran kebijakan publik. Indonesia mempercayai berdirinya bangsa adalah karena Rahmat Tuhan YME; oleh karena itu, Tuhan merupakan kebaikan yang utama. Pengelolaan suatu negara harus diorientasikan pada kebaikan bersama. Penciptaan ruang publik bagi masyarakat adalah menjadi suatu keniscayaan agar tercipta kebijakan yang baik dan mengakomodasi seluruh kepentingan bersama. Lembaga politik sebagai representasi kepentingan rakyat harus memproses aspirasi masyarakat agar menjadi kebijakan yang pro dan baik.

Dalam negara berkembang terdapat dua fakta umum yang menyangkut praktik pemerintahan. Pertama adalah bahwa keahlian perkembangan dan administrasi adalah orang dari institusi pemerintah; oleh karena itu, parlemen sebagai institusi legislatif menjadi begitu tergantung kepada eksekutif selama proses pembuatan hukum. Sebagian besar hukum yang dibuat dibanyak negara berkembang dibuat drafnya oleh eksekutif. Kemudian terlihat legislatif semata-mata hanya mengikuti eksekutif. Oleh karena itu, secara singkat kita dapat menegaskan kembali bahwa proses politik dalam institusi demokratis atau institusi yang kurang menghasilkan kebijakan publik (Nugroho, 2015).

Dalam Suatu berita di harian The Politic membahas mengenai Kapitalisme dibalik penciptaan kebijakan (public policy), dengan headline nya yaitu "Banyak Undang-Undang dan Peraturan Pemerintah dibuat Pro Asing" (The Politic:2012). Dari kasus dalam berita tersebut terlihat jelas bahwa public policy yang bdiperuntukan bagi rakyat pada kenyataannya diperuntukkan bagi pemilik modal, khususnya dalam perekonomian di Indonesia saat ini yang banyak dikuasai oleh pihak asing. Dapat dibenarkan saat ini bahwa Ekonomi Indonesia dijajah Amerika,Eropa dan Negara-negara di Asia sendiri. Contohnya saja kasus pertambangan Freeport yang memiliki unsur ekonomi tertinggi di Indonesia dikuasai oleh Amerika hingga berakhir pada 2020 sesuai dengan 


\section{Ekonomi Indonesia dalam perspektif hukum berkeadilan}

Riski Febria Nurita, La Rian Hidayat

isi dari kontrak karya antara PT Freeport dengan pemerintah Indonesia. Adanya penambangan besar besaran yang mengeruk segala kekayaan yang ada di tanah Papua oleh PT ini menimbulkan efek bagi warga di Papua sendiri keuntungan besar yang didapatkan Freeport tidak memberi perubahan bagi warga Papua, dalam hal ini tidak ada perbaikan apapun bagi warga Papua (Nurita, 2015).

Kenyataan di atas yang membuat warga Papua semakin kecewa dan akhirnya bertindak anarki seperti melakukan pengibaran bendera Bintang Kejora, penembakan kepada karyawan Freeport karena mereka merasa dijajah oleh kebijakankebijakan negara mereka sendiri, mereka merasa hanya kekayaan alam mereka saja yang diambil tanpa memberikan manfaat apa-apa bagi kehidupan warga tanah papua itu sendiri.

Selain itu di bidang perbankan, pihak asing bebas menanamkan modalnya di perbankan dikarenakan ada kebijakan dalam Peraturan Pemerintah Nomor 29 Tahun 1999 yang memperbolehkan individu/lembaga baik lokal maupun asing memiliki suatu bank di Indonesia hingga 99\% kepemilikan saham/modal (Nurita:2015). Di bidang peternakan atau unggas juga hampir sama karena sejak berlakunya Undang-Undang Nomor 18 Tahun 2009, usaha pengunggasan Nasional semakin terpuruk ditandai dengan usaha peternakan rakyat yang gulung tikar secara permanen. Sementara Investasi asing menguasai $60 \%$ pangsa pasar peternakan di Indonesia.

Undang-Undang Nomor 30 Tahun 2007 Tentang Energi juga menyebutkan sektor pertambangan boleh dikuasai asing hingga 95\%. Menurut pengamat intelijen ekonomi Marwan Batubara (Nurita:2015), di bidang perkebunan kini juga dikuasai kapitalisasing dari Asia,faktanya begitu banyak ladang-ladang sawit di Indonesia yang dikuasai Malaysia dan Singapura.

Sebaliknya mengapa BUMN kita tidak kunjung untuk disatukan dan diberikan kesempatan untuk mendapatkan lahan yang lebih luas dengan dibantu permodalannya. Cukup sulit bagi kita untuk membedakan sekaligus melacak perangai pembuat kebijakan di satu pihak dan kapitalisme di lain pihak. Sementara public policy saat ini harus diluruskan dan ditegakkan dari segala bentuk Kapitalisme dan tidak menyalahi prinsip-prinsip ekonomi demi menjamin keberlangsungan investasi dan percepatan perubahan sosial, menuju terwujudnya sistem keadilan sosial yang hakiki.

\section{Simpulan}

Konsep pembangunan Indonesia itu sendiri merupakan upaya pembangunan yang berkesinambungan dalam rangka mewujudkan masyarakat Indonesia yang adil dan makmur berdasarkan Pancasila dan UUD NRI 1945, sehingga mampu menghadapi perkembangan perekonomian yang senantiasa bergerak cepat, kompetitif, dan terintegrasi dengan tantangan yang semakin kompleks

Pada sila kelima Pancasila "Keadilan sosial bagi seluruh rakyat Indonesia" merupakan jiwa filosofis dari Pasal 33 UUD 1945. Ada prinsip yang kuat yang diemban oleh sila kelima Pancasila terkait dengan konsep keadilan dalam mewujudkan kesejahteraan bagi seluruh rakyat Indonesia. Menurut Yudi Latif, otensitas sila kelima ditunjukan dengan kesungguhan negara dalam melindungi segenap bangsa dan seluruh tumpah darah Indonesia berdasarkan persatuan sebagai usaha nyata mewujudkan keadilan sosial.

Keadilan merupakan kebijakan utama dalam institusi sosial, sebagaimana kebenaran dalam sistem pemikiran. Suatu teori, betapapun elegan dan ekonomisnya, harus ditolak atau direvisi jika ia tidak benar. Dengan demikian hukum dan institusi, tidak peduli betapapun betapapun efisien dan rapinya, harus direformasi atau dihapuskan jika tidak adil. Keadilan tidak tunduk pada tawar menawar politik atau kalkulasi kepentingan sosial. Satu-satunya hal yang mengijinkan kita untuk menerima sitem yang salah adalah kerena tidak adanya sistem yang lebih baik. Secara analogis ke- 


\section{Jurnal Cakrawala Hukum, Volume 11 No. 3 Desember 2020}

ISSN PRINT 2356-4962 ISSN ONLINE 2598-6538

tidakadilan bisa kita biarkan hanya ketika ia butuh menghindari ketidakadilan yang lebih besar.

Ekonomi Pancasila adalah sistem ekonomi, atau sistem perekonomian tetapi berbeda dengan sitem ekonomi Kapitalis atau sitem ekonomi Komunis. Sistem ekonomi Pancasila adalah ekonomi yang dijiwai oleh ideologi Pancasila,yaitu sistem ekonomi yang merupakan usaha bersama yang berasaskan kekeluargaan dan kegotong royongan nasional. Kegotong royongan nasional, bukan hanya kegotongroyongan di pedesaan, di rukun kampung, tetapi kegotongroyongan pada tingkat nasional.

Kebijakan publik tidak dibuat dalam keadaan vakum. Kebijakan publik banyak dipengaruhi oleh oleh kondisi sosial dan ekonomi, nilai politik yang berlaku dan suasana hati masyarakat pada suatu waktu. Maka, harus ada konteks yang memicu kelahiran kebijakan publik. Penciptaan ruang publik bagi masyarakat adalah menjadi suatu keniscayaan agar tercipta kebijakan yang baik dan mengakomodasi seluruh kepentingan bersama. Lembaga politik sebagai representasi kepentingan rakyat harus memproses aspirasi masyarakat agar menjadi kebijakan yang pro dan baik.

\section{Daftar pustaka}

Arianto, Satya, 2015, Hak Asasi Manusia dalam Transisi Politik di Indonesia, Pusat Studi Hukum Tata Negara Fakultas Hukum Universitas Indonesia (cetakan ke-3), Jakarta.

Asshiddiqie, Jimly. 2010, Konstitusi Ekonomi. Kompas Media Nusantara. Jakarta.

Badrulzaman, Mariam Darus. 1996. KUHPerdata Buku III Hukum Perikatan dengan Penjelasan. Alumni. Bandung.
Cawley, Peter Mc, 2006. The Economics of Ekonomi Pancasila, Journal Bulletin of Indonesian Economic Studies, Vol 18, Canberra.

Clements, Kevin P. 1999, Teori Pembangunan dari Kiri ke Kanan, Pustaka Pelajar, Yogyakarta.

Fukuyama, Francis, 2002, Trust; Kebijakan Sosial dan Penciptaan Kemakmuran, Qalam, Yogyakarta.

Indrayana, Denny, 2007, Amandemen UUD 1945: Antara Mitos dan Pembongkaran, Mizan, Bandung.

Mubyarto, 1993, Ekonomi Pancasila Gagasan dan Kemungkinan, LP3ES, Jakarta.

Nugroho, Riant. 2015, Kebijakan Publik; Di Negara-Negara Berkembang, Pustaka Belajar, Yogyakarta.

Nurita, Riski Febria. 2015, Kajian Filsafat Hukum Tentang Demokrasi di Indonesia, Jurnal Cakrawala Hukum Vol.6 No.1, Malang.

Raharjo, M. Dawam. 2016 Isu-Isu Kontemporer Ekonomi Pancasila, UNISIA Jurnal Ilmu-Ilmu Sosial. Vol 27. Yogyakarta

Rawls, John. 2011, Teori Keadilan. Pustaka Pelajar. Yogyakarta.

Riant Nugroho, 2009, Public Policy. Alex Media Komputindo, Jakarta.

Ritzer, George dkk. 2011. Teori Marxis dan Berbagai Ragam Teori Neo-Marxian. Kreasi Wacana. Yogyakarta.

Taufiqurrohman Syahuri, Politik Hukum Perekonomian Berdasarkan Pasal 33 UUD NRI 1945, 2012, Jurnal Konstitusi Vol. 9 No. 2, Jakarta.

Thaib, Dahlan. et al, 2004, Teori dan Hukum Konstitusi, Raja Grafindo, Jakarta.

Yudi Latif, 2011, Negara Paripurna; Historisitas, Rasionalitas, dan Aktualitas Pancasila. Gramedia Pustaka Utama, Jakarta. 